\title{
Survival with Technology: Elderly Teachers' Perspective Towards Emergency Online Learning During the COVID-19 Pandemic in the Philippines
}

\author{
*F Samifanni ${ }^{1}$, R L R Gumanit ${ }^{2}$ \\ ${ }^{1}$ Fukuoka International University of Health and Welfare, Japan \\ ${ }^{2}$ Cebu Normal University, Philippines
}

\begin{tabular}{l} 
Article Info \\
\hline Article history: \\
Received November 15, 2021 \\
Revised December 8, 2021 \\
Accepted December 19, 2021 \\
Available Online December 30, 2021 \\
\hline
\end{tabular}

Keywords:

Elderly Teachers

Content Analysis

COVID-19 pandemic

Emergency online learning

Technology

\begin{abstract}
This study analyzed the content of YouTube news clips on elderly teachers concerning emergency online learning during the COVID19 pandemic. Using traditional content analysis, the included news videos were transcribed, interview segments were translated and familiarized, dominant words were identified, data were coded, categorized, and themed. Four dominant words were highlighted: online, students, teachers, and pandemic. Three themes on technical challenges and support needs, health issues, and resilience emerged in the analysis. Results show that elderly teachers are persistent to adapt to emergency online learning despite the struggles they are facing. The analysis also highlights the negative effects of the sudden shift to emergency online learning on the physical and psychological health of elderly teachers. Furthermore, the elderly teachers, are ensuring students' access to education even at their own cost. Implications to the country's quality of education and suggestions of providing better technical and psychological health support to elderly teachers were presented.
\end{abstract}

\section{INTRODUCTION}

Aside from casualties, the coronavirus (COVID-19) pandemic has undesirably stirred the society, economy, and most of all; the education community throughout the globe (Farooq et al., 2020; Niemi \& Kousa, 2020; Samifanni, 2020; Unger \& Meiran, 2020; Çakın \& Akyavuz, 2021; Nnebedum et al., 2021; Paudel, 2021). As of March 2020, there are 107 countries in Africa, Asia, Australia, Europe, North America, and South America that have announced or implemented national school and university closures (UNESCO, 2020a). This has affected almost 1.6 billion learners registered from basic education to university level in 188 nations (UNESCO, 2020b).

In response to the COVID-19 pandemic and in efforts to provide every learner with quality education (SDG4) (Filho et al., 2020), the delivery mode unexpectedly moved from face-to-face or in-person to online teaching (UNESCO, 2020c). This directive of the United Nations Educational, Scientific and Cultural Organization (UNESCO) to abruptly shift to online classes (UNESCO, 2020a) forced people in the academe to implement this transition overnight (Dhawan, 2020; Todd, 2020). This was also true with the elderly teachers who are accustomed to traditional modes of teaching had no choice but to abide by the mandate regardless of their skills or experiences with online instruction. International surveys show that some teachers are considering a career change, resigning, or filing an early retirement due to the shift to online classes (Tate, 2020; Hess, 2020; Nelz, 2020).

Online learning became the lifeline of the academic world after the school shutdowns and re-opening delays caused by the COVID-19 pandemic (Schleicher, 2020). This abrupt variation 
in lesson delivery gave rise to the terms "emergency" online learning/"emergency eLearning" (Murphy, 2020), "emergency remote teaching" (Bozkurt \& Sharma, 2020), and "emergency remote education" (Bozkurt et al., 2020) wherein the instruction is temporarily done virtually through digital or online platforms and alternative means due to the COVID-19 crisis (Adedoyin \& Soykan, 2020; Bao, 2020; Quezada et al., 2020).

The United States "employed remote and hybrid learning" during the COVID-19 crisis (Olneck-Brown, 2021). Moreover, Organization for Economic Co-operation and Development (OECD) instructed its member countries, aside from the U.S., to: utilize their "existing online distance courses whenever possible," persuade education technology (EdTech) corporations to ensure accessible learning resources, use varied and learner-based methods of delivery, and promote collaboration among educators (OECD, 2020). Indian schools and universities adapted online education despite the issue with internet access (Nambiar, 2020). The Ministry of Education in Malaysia introduced a national platform for online education to allow learning as a portion of the nation's strategy of combining face-to-face and online learning during the COVID-19 pandemic (UNICEF, 2020).

In the Philippines, the Department of Education (DepEd) pushed for the continuity of basic education "...even in times of crisis whether it may be a calamity, disaster, emergency, quarantine, or even war" as stated by DepEd Secretary Leonor Briones following the UNESCO advice (Department of Education, 2020). Meanwhile, the Commission on Higher Education (CHEd) advised Higher Education Institutions (HEIs) to pursue the utilization of "flexible learning" and other ways of lesson delivery to replace "on-campus" classes; using the term "flexible learning" is more well-rounded than online learning (Commission on Higher Education, 2020; Parrocha, 2020). Moreover, published reports in the Philippines highlighted the challenges and opportunities as well as faculty perceptions towards online learning as a response to the COVID-19 pandemic (Joaquin, Biana, \& Dacela; Toquero, 2020).

During the COVID-19 crisis, elderly teachers are compelled to use emergency online learning to stay on the job. These elderly teachers, who belong to Generation X or those born from 1965 to 1979, utilize technology mainly for practical purposes and information search (Calvo-Porral \& Pesqueira-Sanchez, 2020). The sudden shift to emergency online learning means elderly teachers have to use online platforms to deliver their lessons. They are to prepare online activities and hold online classes that will require them to use the computer and some applications and software. This may seem easy to younger teachers, but to these elderly teachers, it is a puzzle since they were accustomed to textbooks and chalkboards. Before the pandemic shook the academic world, teaching was not this complicated for these elderly teachers. However, when the "emergency" online learning came, everything became a puzzle piece.

Based on our observations even before the pandemic, elderly teachers are accustomed to the chalk and talk method and preferred the conventional ways of teaching than using multimedia or PowerPoint presentations during their lessons. Using online learning platforms and software became a huge problem for elderly teachers because they find it hard to follow prompts and commands; it became too complicated for them. Having this in mind, we were curious about how the elderly teachers view this rapid shift in teaching modality. Therefore, the conduct of this study will generate new knowledge about elderly teachers' perspective towards "emergency" online learning and will also help school administrators on how to support the seasoned teachers in using and adapting to the online mode of instruction to deliver quality instruction.

\section{Research Objectives}

The aim of this study was to analyze the content of YouTube news clips on elderly teachers concerning online classes during the COVID-19 pandemic in the Philippines. Specifically, it aimed to: 
1. Identify the dominant terms found in the news clips; and

2. Identify the elderly teachers' perspective towards emergency online learning during the covid-19 pandemic.

\section{Literature Review}

Sun and Chen (2016) claimed that different models and investigations about online education have been endorsed for many years. Before the COVID-19 crisis, these scholarly investigations about online education mainly concentrated on tertiary level education leaving those in the basic education behind (Lestari \& Gunawan, 2020). A study scrutinized how teaching innovation such as blended learning was employed based on certain features like difficulty and "trialability" (Grgurovic, 2014), however, during the COVID-19 crisis the rapid move to online learning was too unexpected which made trials of varied teaching innovation an unworkable task.

Online learning, also known as distance education, e-learning, online education, or remote learning is defined by the United States Distance Learning Association (USDLA) as attaining information and aptitude over facilitated teaching and learning to comprise all "technologies and other forms of learning at a distance" (USDLA, 2010). For Watson et al. (2008), online learning is a form of education where the instructor leads the class via the Internet wherein the participants are geographically separated. The term "emergency" is attached to online learning due to its abrupt nature of teaching modality shift in response to the COVID-19 pandemic (Adedoyin \& Soykan, 2020; Bao, 2020; Bozkurt \& Sharma, 2020; Murphy, 2020; Quezada et al., 2020).

Prior to and during the COVID-19 pandemic, studies towards online learning focused on students' and teachers' perspectives in general (Kulal \& Nayak, 2020; Nambiar, 2020; Forson \& Vuopala, 2019). Although online learning offers to teach flexibility and convenience as Reinders and White (2010) claimed, other studies emphasized the drawbacks in the utilization of online learning suggesting it is socially and affectively less engaging for the students (Baralt et al., 2016) while teachers underscored the difficulties in accomplishing some learning points and in measuring the responses of the learners (Todd, 2020). There is a limited number of studies pertaining to the transition from in-class to emergency online instruction during the COVID-19 pandemic. Refereed researches related to COVID-19 and online learning commonly highlight instructors' perspectives and experiences (Simamora et al., 2020; Damşa et al., 2021). The same is true for many evaluation studies except for those which include instructors but either did not distinguish reporting the survey results of the instructors from the learners (Slimi, 2020) or only reported general thoughts and advice regarding the shift (Dhawan, 2020; Rapanta et al., 2020; Rashid \& Yadav, 2020).

On one hand, there are studies that emphasized teachers' views towards emergency online learning during the pandemic. The study of Fox et al. (2020) reported that teachers in the U.S. who belong to schools with operating online facilities had a more positive opinion of the effect of online instruction. They also indicated that Information Technology (IT) utilization and academic support to the staff seems relatively high. After the first semester since the pandemic in Norway; Dolonen et al. (2020) scrutinized the answers of 826 school teachers and found that although many were inexperienced with online instruction, they were able to swiftly familiarize themselves with the "new technologies" and seek out help (including IT) from fellow teachers. On the other hand, teachers reported that online instruction is more time-consuming in terms of lesson planning and makes learning less engaging. Other studies had parallel yet diverse results; in their research, Hjelsvold et al. (2020) reported that teachers had advanced pre-online skills and encouraging exposure to the emergency online learning transition. However, they complained about their lack of teaching competence with online instruction. Yang (2020) surveyed 15,438 Chinese instructors and stated that instructors generally advocate online instruction in response to the pandemic but they raised some apprehensions. In Italy, university 
instructors involved in the online shift were pessimistic compared to primary and secondary school instructors; they also were unwilling to innovate their instruction (Giovannella \& Passarelli, 2020).

Regarding the literature about online learning adaptation during the pandemic, reports were divided. In a survey from thirteen countries in Europe, the report stated that instructors swiftly and confidently adapted the online means of teaching; but many expressed their desire for going back to conservative approaches past "the first lockdown" (Tartavulea et al., 2020). Concurrently, there is a positive connection between sophisticated school support and confidence towards the online teaching framework with the expectations on the efficacy of online instruction (Tartavulea et al., 2020). However, some studies revealed worrying reports. One is the research of Watermeyer et al. (2020) which revealed that United Kingdom (UK) educators experienced numerous "afflictions," and that online instruction is causing notable distress and trouble to their academic duties and their private lives. Also, the instructors' adjustment to innovative technology was a hindrance viewed in online instruction due to the difficulty in training staff with using this "new technology" instantaneously (Khan et al., 2021). In India, Nambiar (2020) discovered that despite the problems experienced by many towards emergency online learning, some approved that this modality opened their awareness on their capacity stressing the possibility designed for the modified influence of "digitalization" on education. Arora \& Srinivasan (2020) indicated the disadvantages faced by instructors who implemented online learning. They emphasized that instructors encountered lesser "actual benefits" than their expectations such as internet problems, insufficient training, and insufficient knowledge in online teaching; with the latter as the most prominent issue. The instructors' lack of knowledge about online learning was the main reason why some instructors refused to implement virtual lessons along with their disinterest and uncertainties concerning the benefits of online learning. Moreover, online instruction revealed notable disadvantages namely lesser attendance, "personal touch" absence, and minimal participation because of internet issues (Arora \& Srinivasan, 2020).

Present studies on educators' application and employment of emergency online learning revealed the difficulties linked with below standard online teaching framework, technical and instructional hindrances, digitally unskilled instructors, "information gap" (i.e., limited information and resources), and unsuitable home-based teaching atmosphere (Hassan et al., 2020; Khan et al., 2021; Mishra et al., 2020; Murgatrotd, 2020; Zhang et al., 2020). In addition, studies also identified a lack of technical mentoring and support (British Council, 2020; Hamilton et al., 2020; Judd et al., 2020) and concerns related to teachers' competencies in the use of digital instructional formats and insecurity in using new technology on short notice (Huber \& Helm, 2020; Damşa et al., 2021). Moreover, teachers raised concerns about their health and mental well-being with the home-based setup during the online shift due to feelings of seclusion, ill-fitted workplace, excessive screen time, psychological troubles and challenges, and stress (MacIntyre et al., 2020; Akour et al., 2020; Besser et al., 2020; Ribeiro et al., 2020). On the contrary, some instructors are strongly focused on their professional advancement to improve online instruction during the COVID-19 crisis (British Council, 2020; Daumiller et al., 2021).

Published reports in the Philippines highlighted the challenges and opportunities as well as faculty perceptions towards online learning as a response to the COVID-19 pandemic (Joaquin et al., 2020; Toquero, 2020). However, at the point of writing, there is no discussion focusing on elderly teachers' perception towards the "emergency" online instruction due to the COVID-19 pandemic. Before the COVID-19 crisis, studies tackled the elderly teachers' attitude (Tariq et al., 2019) and the extent of information communication technology (ICT) utilization in their instruction and profession (Theng \& Hua, 2008); unlike the current situation with the emergency online learning where classes are done online, few can be learned from the literature. Therefore, employing research into the perspectives of elderly teachers toward emergency online learning during the COVID-19 pandemic is important to fill this gap. 


\section{RESEARCH METHOD}

\section{Research Design}

This qualitative study utilized content analysis to analyze print or electronic media, such as newspapers, radio, television, and film (Eriyanto, 2011). This method was formerly employed in many fields such as research on natural phenomena (Chandelier et al., 2018; Bhatia et al., 2013; Billett, 2010; Jacobson et al., 2012); political analysis (Bauer et al., 2017); and education (Blei, 2012). This method enables the researchers to autonomously formulate topics by evaluating the news contents and exploring the variation of contents over time (Blei, 2012; Roberts et al., 2013). Additionally, examining the variety of contents in news reports through content analysis can support in having a better understanding of the various features of pandemics concerning its consequences to society, politics, and economy (Westgate et al., 2015). Since news video falls under electronic media, it is appropriate to use content analysis for this study.

\section{Sample}

Using purposive sampling (Patton, 2002), YouTube news videos were utilized in this study (Creswell, 2013). These news videos met the following criteria: most viewed Philippine-based news reports in English regardless of the interview segment, only news videos with "elderly teachers or senior teachers" in the title/ headline, and aired from October to December 2020 were included in this study. Meanwhile, news videos are excluded if they are focused on: students' and parents' views and challenges about online learning, special education and online learning, online learning in general, and comments of videos.

\section{Data collection}

"Elderly teachers", "senior teachers", "Philippines", "Filipino", "online learning", "COVID-19" will be the set keywords for news videos searching in this study. Using google video and YouTube search, 91 news clips contained these keywords with the earliest report which appeared in April 2020. This number was reduced to 52 after identifying duplicates (9) and early date of airing (30). Another 23 news videos were excluded because they focused on students' and parents' views and challenges about online learning. Moreover, 16 more news videos were excluded because they focused on special education and online learning. Lastly, 11 news videos were excluded because they focused on online learning in general. Among all, two news videos with a specific focus on Filipino elderly/senior teachers and online classes were set as key news videos for further analysis. Furthermore, the comments of the included news videos and side interviews were excluded for analysis.

\section{Data}

The data for this study were the YouTube news videos on elderly teachers and online learning during the COVID-19 pandemic uploaded by Rappler (2020) on October 8, 2020, and by ANC (2020) on October 3, 2020 (Figure 1). The news videos run between 3 to 6 minutes and have an average 7,655 of views as of November 2021. 

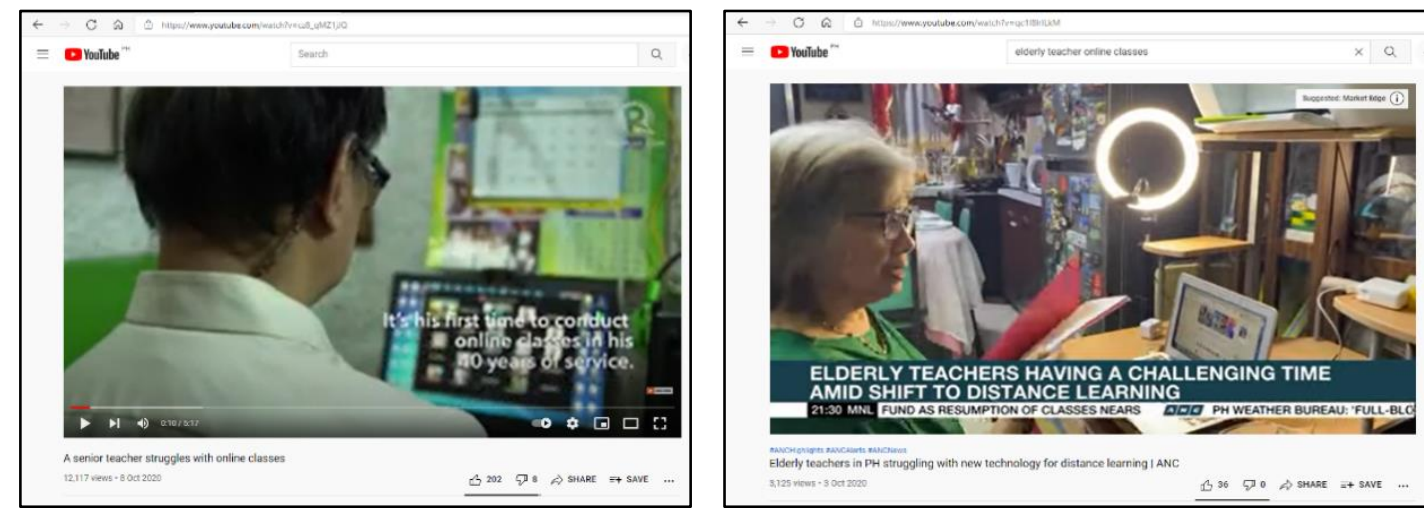

Figure 1. Screenshots of YouTube news videos

\section{Data analysis}

The study utilized traditional content analysis (Hsieh \& Shannon, 2005) in analyzing textual data from the video transcripts without predefined categories which allowed patterns, codes, and themes to emerge from the textual data. The thematic units were used to understand the latent content (Graneheim \& Lundman, 2004) of the video transcripts presented in the news videos. In this study, the news videos were considered as the unit of analysis. The researchers downloaded the news videos and immediately transcribed them. Then, the interview segments which were in Filipino were translated to English and reviewed to gain a general understanding of the data. After that, each summarized unit was abstracted and named with a code by the researchers. The codes were then grouped according to likenesses and merged to find themes. Next, the themes were reviewed, defined, and named. The final step is producing the report (Fig. 2). The researchers used online software (Zygomatic, 2003) to identify the dominant words from the transcripts; coding was done manually.

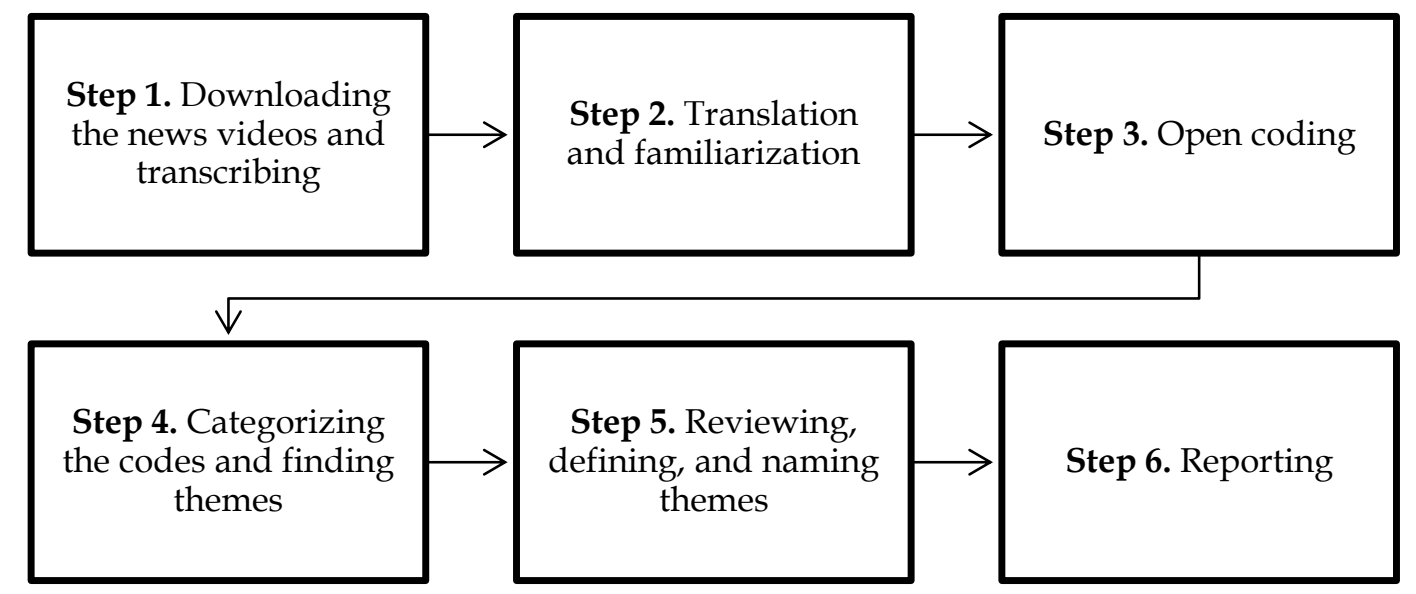

Figure 2. Data analysis flowchart

\section{Research rigor}

The authors followed the Lincoln and Guba (1986) criteria to establish the trustworthiness of the study. We spent a long time on data collection and repetitively studied the data to become immersed in it. Another was member checking and data verification to ensure the credibility of the data. To enhance data dependability, the research findings were examined and validated by experts in the field of qualitative research who were not involved in data collection and analysis, and had no conflict of interest. It means that the video transcripts, along with the relevant codes and themes were examined and confirmed. The suggestions and review of the panel of experts were utilized to improve data confirmability. Regarding data transferability, 
we provided a clear outline of the methodical process and presented a detailed description of the phenomenon. Moreover, we transcribed the participants' sentences verbatim and translated them from Filipino to English.

\section{Ethical consideration}

YouTube meets the criteria for a public online database (public domain) as it is free, publicly accessible without requiring registration, and has a large membership size. YouTube was accessed without a registered account to ensure accessed videos were publicly available and had no age restrictions (Alexa, 2018; Eysenbach \& Till, 2001; Lewis et al., 2012).

\section{RESULTS AND DISCUSSION}

The data analysis revealed four dominant words (Figure 2) and three main themes which emerged from the transcripts of the news videos: technical challenges and support needs, health issues, and resilience (Table 1).

The translated transcripts were run in an online software to tabulate all messages contained therein. A "word cloud" (in which a word's size is proportional to its frequency) was generated in wordcloud.com to provide a graphic representation of the dominant words (Fig. 3).

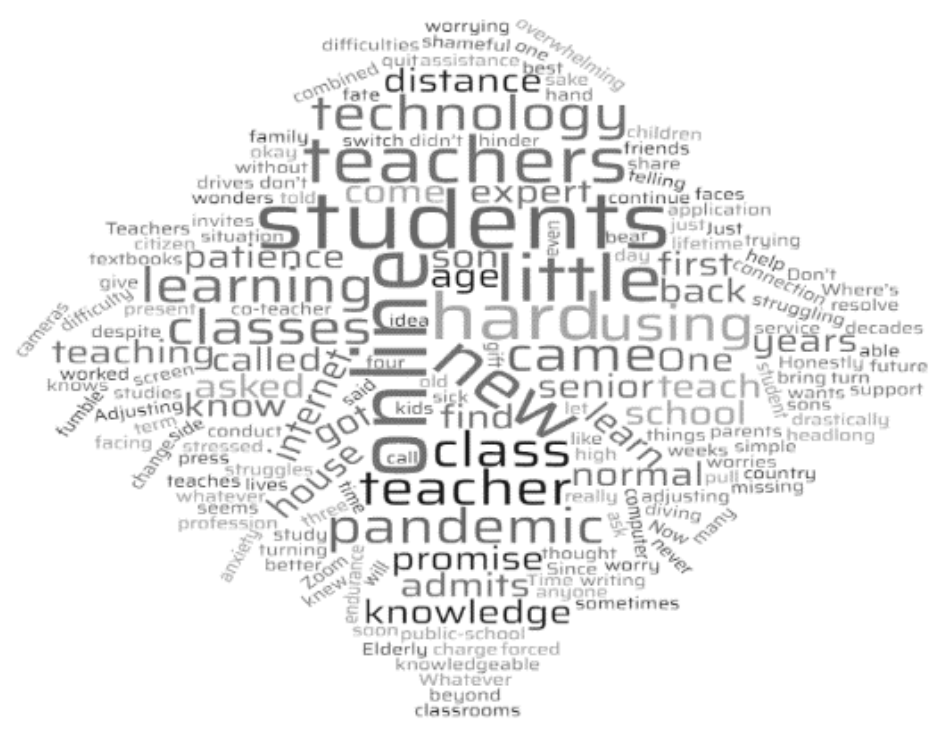

Figure 3. Word cloud of dominant words

Excluding function words, the dominant words out of 484 terms in the transcripts are online, students, pandemic, and teachers. The string words for online ( $\mathrm{fN}=0.016$ ) are: class, classes, learning, Hard, distance, find, first, internet, knowledge, learn, teach, teaching, adjusting, able, anxiety, new, technology, using, expert, application, ask, assistance, call, cameras, co-teacher, combined, computer, conduct, connection, day, difficulty, difficulties, faces, help, know, many, missing, overwhelming, press, pull-off, said, screen, side, simple, son, sons, struggle, struggling, switch, term, things, turn, turning, without, whatever, Zoom. Next is students ( $\mathrm{fN}=0.016$ ) with these string words: Asked, called, come, one, patience, little, anyone, bear, better, bring, children, charge, future, gift, high school, kids, parents, sake, student, studies, study, telling, told, wants. Third, is teachers ( $\mathrm{fN}=0.008)$ with the following string words: Teacher, Admits, Age, even, back, got, house, promise, senior, years, best, beyond, change, citizen, classrooms, continue, country, decades, diving, drives, elderly, endurance, facing, family, fate, four, friends, fumble, give, hand, headlong, hinder, honestly, idea, invites, knew, knowledgeable, knows, let, lifetime, like, never, okay, old, profession, public-school, quit, resolve, service, shameful, share, sick, stressed, support, teaches, textbooks, thought, three, 
trying, weeks, wonders, worked, worries, worry, worrying, writing. The last dominant word is pandemic ( $\mathrm{fN}=0.006$ ) having these string words: Came, normal, school, time, despite, drastically, forced, lives, present, situation. Some big words which are related to the key dominant word such as "technology" "hard", and "new" were considered as string words.

After data analysis, there are three major themes and 10 categories that were extracted from the news videos transcripts as presented in the following table.

Table 1. The emerging themes and categories from the news videos

\begin{tabular}{ll}
\hline Themes & Categories \\
\hline Technical Challenges and Support Needs & Technical difficulties \\
& Technical ineptitude \\
& Need for technical mentors \\
Health Issues & Disinterest in online learning \\
& Stress and anxiety \\
Resilience & Illness \\
& Persistence \\
& Idealism \\
& Optimism \\
& Student Welfare \\
\hline
\end{tabular}

\section{Technical Challenges and Support Needs}

The first theme refers to the technical challenges and support needs which refers to the difficulties faced by the elderly teachers in using online learning. The most common codes are present in this theme which contains three more related categories including technical difficulties, technical ineptitude, disinterest in online learning, and need for technical mentors.

The first category under this theme is technical difficulties. The elderly teachers reported that it is a challenge for them to adjust to the emergency online learning. Teacher 1 said: "With my age, being 61, I find it hard. Adjusting is hard for me." They also find it hard to follow and do simple application commands to hold online classes. Teacher 2 ascertained: "I find it hard as simple as turning on and off (the application). There are many difficulties."

Technical ineptitude is the second category that focuses on the elderly teachers' lack of technical knowledge about online learning. Teacher 1 said: "I do not know, I have no idea." Teacher 2 commented: "Just turn on Zoom. Whatever, whatever term you call it. Son, how to do this? What should I press?"

The third category focused on the elderly teachers' need for technical mentors. Since they are not skilled in using online platforms in conducting classes, they have a strong need for someone "on-call" to assist them so they can conduct online classes. Teacher 2 said: "And then when all faces of my students (cameras) were combined, I asked my son: Where's the other one? One is missing. There are many difficulties." "I really asked my co-teacher to teach me and I called a high school student who has knowledge in using the computer." "I just ask for assistance so I would not be shameful to the students that I am teaching," said Teacher 1.

The fourth category under the first theme is disinterest in online learning. Teacher 1 said: "Honestly, I am not into using online technology."

\section{Health Issues}

The second theme refers to the health issues which focused on the health concerns faced by the elderly teachers in using online learning. This theme covers two categories: stress and anxiety, and illness. 
The first category was about stress and anxiety due to the shift to emergency online learning. Teacher 1 said: "I got stressed because I thought how and what should I do with online class."

Illness is the second category for health issues. Teacher 1 said: "So, when this pandemic came and they (school leaders) said that we will switch to online (classes), I got sick for three weeks."

\section{Resilience}

The third theme mentions the resilience of the elderly teachers in using online learning. This theme could be described in these categories: persistence, idealism, optimism, and student welfare.

Persistence is the first category under the third theme. "I also worked hard to learn," said Teacher 1 .

The second category for the third theme is the idealism of the elderly teachers. "Since I am a teacher and I have to be knowledgeable, I have to know what to do," according to Teacher 1.

Optimism is another important category this showed the strong resolve and positivity of the elderly teachers in these trying times and in adapting to the online mode of teaching. Teacher 1 said "A little endurance, a little patience because this is not for a lifetime. Time will come that our lives will go back to normal." Teacher 2 said, "Don't worry, your teachers are trying their best to be an expert in using this new technology so we can give you a better future."

Student welfare is the fourth category which involves the elderly teachers' concern for their students to ensure access to education. Teacher 1 said "I called those students telling them; 'if anyone wants to study online class, I have an internet connection. I will not charge you.' It is my gift to the students for them to continue their studies despite the present situation with the pandemic. I told my students, bear it a little. To the parents, a little more patience; bring your kids here."

\section{Discussion}

This study analyzed the content of YouTube news clips on elderly teachers concerning emergency online learning during the COVID-19 pandemic. The findings suggest that the dominant words in the transcribed videos were related to the pandemic and online learning. Also, it was found that the elderly teachers faced challenges and hardships with the shift to emergency online learning, but were trying to do their duty as educators.

Elderly teachers expressed their disinterest and challenges towards the online teaching modality. They stated that following simple commands gives them difficulties in facilitating online classes. Furthermore, since elderly teachers are disinterested in this technology, they have little to no technical know-how and do not know what to do with online classes. Therefore, elderly teachers find that adjusting and adapting to online learning is hard for them (Khan et al., 2021). This agrees with other studies which stated that teachers lacked pedagogical knowledge (Yang \& Cornelius, 2004) and had not enough time to learn using the platforms of online learning on short notice (Damşa et al., 2021). However, this finding respectfully disagrees with the findings of Dolonen et al. (2020) and Tartavulea et al. (2020) which stated that teachers, in general, were quick and positive in adapting to online learning. This study argues that this might not be the case for elderly teachers. This indicates that elderly teachers may not provide optimum instruction in online classes and as a backlash, students may show dissatisfaction with their courses when instructors were unavailable to provide technical support since technical issues were found to be the most influential factor when it came to satisfaction with online classes (Yang \& Cornelius, 2004; Mishra et al., 2020; Nambiar, 2020). Furthermore, these challenges could lead to fear among the elderly teachers of being asked to quit the job (Khanna \& Kareem, 2021). During the COVID-19 pandemic, elderly teachers are required and "have to" 
adopt the emergency online learning similar to the study of Tariq et al. (2019) where elderly teachers are obliged to adopt innovation to keep their job. It is noteworthy and interesting that the elderly teachers in the YouTube news clips made no mention of career change nor resignation despite their struggles with online classes, this opposes the results of surveys (Tate, 2020; Hess, 2020; Nelz, 2020) aforementioned. This feeling of the elderly teachers being obliged to use technology in teaching does not agree with the claim of Theng and Hua (2008) stating that elderly teachers showed eagerness and interest in using technology in teaching and profession.

Regarding the need for technical mentors, the elderly teachers pointed out seeking technical assistance from techy colleagues and students upon knowing the shift to online classes and during the conduct of their classes. It was also mentioned that immediate family members were on-call to help the elderly teachers with their online classes. This was also cited in the studies of Yang and Cornelius (2004), Hamilton et al. (2020), and Damşa et al. (2021), where teachers needed to seek out forms of support beyond the regular support provided by their institution. It appears that although schools are providing support, it is still lacking (Khanna \& Kareem, 2021; British Council, 2020) especially to the teachers in this age group. Therefore, it is critical to provide adequate support to educators in this endeavor (Moser et al., 2021) especially the elderly teachers.

Health issues is the second theme of this study. A comment by one of the elderly teachers admitting of being sick upon learning about the shift to online classes was a sign of concern. This was due to the stress and anxiety of the abrupt shift and readiness towards online classes (MacIntyre et al., 2020; Akour, et al., 2020). Similar results were obtained from other studies, where faculty members had higher levels of psychological stress and health concerns during the transition to online synchronous teaching compared with previous periods of teaching (Besser et al., 2020; Ribeiro et al., 2020). It seems that the abrupt shift to online learning is highly straining the psychological and physical health of elderly teachers.

Another important finding of this study was the resilience of elderly teachers in learning and adapting to emergency online learning despite their struggles with technology. The elderly teachers emphasized that with their persistence and idealism, they are striving hard to deliver what is expected of them. Online teaching was seen as a positive challenge and as useful for teachers' competence development (Daumiller et al., 2021; British Council, 2020). This suggests that elderly teachers are willing to go the extra mile and exert an extra effort to grow intellectually and professionally despite the difficulties they are facing. Another category under this theme is optimism and student welfare. This concerns the elderly teachers' positive attitude saying that this pandemic is "temporary and life will go back to normal." Patience and endurance were also pointed out. Stachteas and Stachteas (2020) reported that teachers are distinct for their mental resilience, this characteristic is likely to favorably add to their effectivity despite the complexity of the nature of their work which they firmly hope to return to the way it was before the pandemic. This shows that elderly teachers are hopeful that life and teaching will go back to how they usually teach and that this hardship will be over. Nevertheless, assisting students with internet access was also stated. It also shows that teachers are constantly thinking about the welfare of their students (Moser et al., 2021) and are doing what they can to ensure access to education at their own expense.

\section{CONCLUSION}

This study analyzed the content of YouTube news clips on elderly teachers concerning emergency online learning during the COVID-19 pandemic. Overall, the results of this study suggest that elderly teachers are struggling in adapting to emergency online learning but are determined to learn, improve, and meet expectations. The analysis made no mention of elderly teachers leaving the profession due to online learning. The implementation of online learning in the Philippines is another hurdle to providing quality education. The issue with elderly teachers 
only adds to the list of challenges that needs attention from the school administration and the teaching field. Action needs to be taken soon so that the Philippines quality of education will improve.

\section{RECOMMENDATIONS}

The findings of this study suggest that schools need to give more attention to providing technical support to elderly teachers to improve their competence and confidence in conducting online classes. This also suggests that "one-size-fits-all" technical training does not and cannot be applied to elderly teachers who are struggling with emergency online learning. Whenever possible, the school's Information Technology (IT) department should design learning platforms that only require a few commands so elderly teachers can easily follow. Furthermore, school leaders may also want to consider creating a virtual faculty and staff community focused on mental well-being with an expert to address the concerns in the field and the elderly members of the faculty. Future research could focus on a larger sample using the quantitative method.

\section{LIMITATIONS}

The limitations of the present study were the small sample size and scope of data.

\section{AUTHOR CONTRIBUTIONS}

Rose Leslie Gumanit transcribed the news videos and translated the video transcripts; wrote the first draft, while Dr. Faramarz Samifanni wrote the final draft and edited the manuscript.

\section{CONFLICT OF INTEREST}

The authors declare no conflict of interest.

\section{ACKNOWLEDGEMENTS}

The authors extend their deepest gratitude to the Creator for the gift of life. Their greatest thanks to many Japanese and Filipino colleagues, friends, and students who made their lives more meaningful. A special thanks to Fukuoka International University of Health and Welfare leaders.

\section{REFERENCES}

Adedoyin, O. B., \& Soykan, E. (2020). Covid-19 pandemic and online learning: The challenges and opportunities. Interactive Learning Environments, 1-13. https:// doi.org/10.1080/10494820.2020.1813180

Alexa. (2018). Youtube.com Traffic Statistics. https://www.alexa.com/siteinfo/youtube.com

Akour, A., Al-Tammemi, A. B., Barakat, M., Kanj, R., Fakhouri, N. H., Malkawi, A., \& Musleh, G. (2020). The impact of the COVID-19 pandemic and emergency distance teaching on the psychological status of University teachers: A cross-sectional study in Jordan. American Journal of Tropical Medicine and Hygiene, 103(6), 2391-2399. https://doi.org/10.4269/ajtmh.20-0877

ANC. (2020, October 3). Elderly teachers in PH struggling with new technology for distance learning I ANC [Video]. YouTube. https://www.youtube.com/watch?v=qc1181rILkM

Arora, A. K., \& Srinivasan, R. (2020). Impact of pandemic COVID-19 on the teaching - learning process : A study of higher education teachers. Prabandhan: Indian Journal of Management, 13(4), 43. https:// doi.org/10.17010/pijom/2020/v13i4/151825

Bao, W. (2020). COVID-19 and online teaching in higher education: a case study of peking university human. Behavior and Emerging Technologies, 2, 113-115. https:// doi.org/10.1002/hbe2.191 
Baralt, M., Gurzynski-Weiss, L., \& Kim, Y. (2016). 8. Engagement with the language: How examining learners' affective and social engagement explains successful learner-generated attention to form. Language Learning $\mathcal{E}$ Language Teaching, 45, 209-239. https:// doi.org/10.1075/11lt.45.09bar

Bauer, P., Pablo, B., Ackermann, K., \& Aaron, V. (2017). Is the left-right scale a valid measure of ideology? Individual-level variation in associations with "left" and "right" and left-right self-placement. Polit Behav, 39, 553-583. https://doi.org/10.1007/s11109-016-9368-2

Theng, L. B., \& Hua, S. C. (2008). Exploring the extent of ICT adoption among secondary school teachers in Malaysia. International Journal of Computing and ICT Research, 2(2), 19-36.

Besser, A., Lotem, S., \& Zeigler-Hill, V. (2020). Psychological Stress and vocal symptoms among University professors in Israel: Implications of the shift to online synchronous teaching during the COVID-19 pandemic. Journal of Voice in Press. https:// doi.org/10.1016/j.jvoice.2020.05.028

Bhatia, S., Athreya, V., Grenyer, R., \& MacDonald, D. (2013). Understanding the role of representations of human-leopard conflict in Mumbai through media-content analysis. Conserv Biol, 27(3), 588-594. https:// doi.org/10.1111/cobi.12037

Billett, S. (2010). Dividing climate change: global warming in the Indian mass media. Clim. Change, 99, 1-16. https:/ / doi.org/10.1007/s10584-009-9605-3

Blei, D. (2012). Probabilistic topic models. Commun. ACM, 55, 77-84. https:// doi.org/10.1145/2133806.2133826

Bozkurt, A., \& Sharma, R. C. (2020). Emergency remote teaching in a time of global crisis due to coronavirus pandemic. Asian Journal of Distance Education, 15(1), 1-6.

Bozkurt, A., Jung, I., Xiao, J., Vladimirschi, V., Schuwer, R., Egorov, G., Lambert, S. R., Al-Freih, M., Pete, J., Olcott, Jr., D. Rodes, V., Aranciaga, I., Bali, M., Alvarez, Jr., A. V., Roberts, J., Pazurek, A., Raffaghelli, J. E., Panagiotou, N., de Coëtlogon, P., . . Paskevicius, M. (2020). A global outlook to the interruption of education due to COVID-19 pandemic: Navigating in a time of uncertainty and crisis. Asian Journal of Distance Education, 15(1), 1-126. https://doi.org/10.5281/zenodo.3778083

British Council. (2020). English language teaching and COVID-19: A survey of teacher and educator needs during the COVD-19 pandemic, April - May 2020. Britich Council. https://www.teachingenglish.org.uk/sites/teacheng/files/covid19-teacher-teacher educator-survey.pdf

Çakın, M., \& Akyavuz, K. E. (2021). Educational adventure of students in the COVID-19 period in Turkey: Determination of parents' views. International Journal on Social and Education Sciences (IJonSES), 3(1), 109-125. https://doi.org/10.46328/ijonses.87

Calvo-Porral, C., \& Pesqueira-Sanchez, R. (2020). Generational differences in technology behaviour: Comparing millennials and Generation X. Kybernetes, 49(11), 2755-2772. https:// doi.org/10.1108/K-09-2019-0598

Chandelier, M., Steuckardt, A., Mathevet, R., Diwersy, S., \& Gimenez, O. (2018). Content analysis of newspaper coverage of wolf recolonization in France using structural topic modelling. Biol. Conserv, 220, 254-261. https:// doi.org/10.1016/j.biocon.2018.01.029

Commission on Higher Education. (2020). Guidelines for the prevention, control and mitigation of the spread of coronavirus disease 2019 (COVID-19) in Higher Education Institutions (HEIs). Office of The Chairperson Commission on Higher Education. https://ched.gov.ph/wpcontent/uploads/CHED-COVID-19-Advisory-No.-6.pdf

Creswell, J. (2013). Qualitative inquiry \& research design: Choosing among the five approaches. SAGE Publications, Inc.

Damşa, C., Langford, M., Ueharaa, D., \& Scherer, R. (2021). Teachers' agency and online education in times of crisis. Computes in Human Behavior, 121, 106793. https://doi.org/10.1016/i.chb.2021.106793 
Daumiller, M., Rinas, R., Hein, J., Janke, S., Dickhäuser, O., \& Dresel, M. (2021). Shifting from face-to-face to online teaching during COVID-19: The role of university faculty achievement goals for attitudes towards this sudden change, and their relevance for burnout/engagement and student evaluations of teaching quality. Computers in Human Behavior, 118, 106677. https://doi.org/10.1016/j.chb.2020.106677

Department of Education. (2020). Learning while staying at home: Teachers, parents support deped distance learning platform. Republic of The Philippines Department of Education. https:// www.deped.gov.ph/2020/03/21/learning-while-staying-at-home-teachersparents-support-deped-distance-learning-platform/

Dhawan, S. (2020). Online learning: A panacea in the time of COVID-19 crisis. Journal of Educational Technology Systems, 49(1), 5-22. https://doi.org/10.1177/0047239520934018

Dolonen, J., Daehlen, M., Enli, G., Ludvigsen, S., \& Morken, K. (2020). Digital undervisning ved det samfunnsvitenskapelige fakultet 12.3-2.4. Universitetet in Oslo. https://www.sv.uio.no/iss/om/organisasjon/programradene/sosiologi/moter/2020/20 20-06-03/sv-digital-undervisning-rapport.pdf

Eriyanto. (2011). Analisis isi: Pengantar metodologi untuk penelitian ilmu komunikasi dan ilmu-ilmu sosial lainnya. Prenadamedia Group

Eysenbach, G., \& Till, J. (2001). Ethical issues in qualitative research on internet communities. BMJ, 323(7321), 1103-1105. https:// doi.org/10.1136/bmj.323.7321.1103

Farooq, F., Rathore, F. A., \& Mansoor, S. N. (2020). Challenges of online medical education in Pakistan during COVID-19 pandemic. Journal of College of Physicians and Surgeons, 30(6), 6769. https:// doi.org/10.29271/jcpsp.2020.Supp1.S67

Filho, W., Brandli, L., Salvia, A., Rayman-Bacchus, L., \& Platje, J. (2020). COVID-19 and the UN Sustainable Development Goals: Threat to solidarity or an opportunity?. Sustainability, 12(13), 5343. https://doi.org/10.3390/su12135343

Forson, I. K., \& Vuopala, E. (2019). Online learning readiness: Perspective of students enrolled in distance education in Ghana. The online journal of distance education and e-learning, 7(4), 277-294.

Fox, K., Bryant, G., Srinivasan, N., Lin, N., \& Nguyen, A. (2020). Time for class - COVID-19 edition Part 2: Planning for a fall like no other. Tyton Partners. https:/ / tytonpartners.com/library/time-for-class-covid-19-edition-part-2/

Giovannella, C., \& Passarelli, M. (2020). The effects of the COVID-19 pandemic seen through the lens of the Italian university teachers and the comparison with school teachers' perspective. Interaction Design and Architecture(s) Journal, 46, 120-136.

Graneheim, U., \& Lundman, B. (2004). Qualitative content analysis in nursing research: Concepts, procedures and measures to achieve trustworthiness. Nurse Education Today, 24(2), 105-112. https:/ / doi.org/10.1016/j.nedt.2003.10.001

Grgurovic, M. (2014). An application of the diffusion of Innovations theory to the investigation of blended language learning. Innovation in Language Learning and Teaching, 8(2), 155-170.

Hamilton, L. S., Kaufman, J. H., \& Diliberti, M. K. (2020). Teaching and leading through a pandemic: Key findings from the american educator panels spring 2020 COVID-19 surveys. RAND Corporation. https://www.rand.org/pubs/research_reports/RRA168-2.html

Hassan, M. M., Mirza, T., \& Hussain, M. W. (2020). A Critical review by teachers on the online teaching-learning during the COVID-19. International Journal of Education and Management Engineering, 10(5), 17-27. https://doi.org/10.5815/ijeme.2020.05.03

Hess, A. J. (2020, December 14). 27\% of teachers are considering quitting because of Covid, survey finds. CNBC. https://www.cnbc.com/2020/12/14/27percent-of-teachers-areconsidering-quitting-because-of-covid-survey.html

Hjelsvold, R., Nykvist, S., Lorås, M., Bahmani, A., \& Krokan, A. (2020). Educators' experiences online: How COVID-19 encouraged pedagogical change in CS education. Norsk IKTKonferanse for Forskning Og Utdanning, 2020(4). 
Hsieh, H., \& Shannon, S. (2005). Three approaches to qualitative content analysis. Qualitative health research, 15(9), 1277-1288. https:/ / doi.org10.1177/1049732305276687

Huber, S. G., \& Helm, C. (2020). COVID-19 and schooling: Evaluation, Assessment and accountability in times of crises - reacting quickly to explore key issues for policy, practice and research with the school barometer. Educational Assessment, Evaluation and Accountability, 32, 237-270. https:// doi.org/10.1007/s11092-020-09322-y

Jacobson, S., Langin, C., Carlton, J., \& Kaid, L. (2012). Content analysis of newspaper coverage of the Florida panther. Conserv. Biol, 171-179. https://doi.org/10.1111/j.1523 1739.2011.01750.x

Judd, J., Rember, B. A., Pellegrini, T., Ludlow, B., \& Meisner, J. (2020). "This is not teaching": The effects of COVID-19 on teachers. Social Publishers Foundation. https:// www.socialpublishersfoundation.org/knowledge_base/this-is-not-teaching-theeffects-of-covid-19-on-teachers/

Khan, A. M., Patra, S., Vaney, N., Mehndiratta, M., \& Chauhan, R. (2021). Rapid transition to online practical classes in preclinical subjects during COVID-19: Experience from a medical college in North India. Medical Journal Armed Forces India, 77(1), S161-S167. https:// doi.org/10.1016/j.mjafi.2020.12.030

Khanna, R., \& Kareem, D. J. (2021). Creating inclusive spaces in virtual classroom sessions during the COVID pandemic: An exploratory study of primary class teachers in India. International Journal of Educational Research Open, 2(2), 100038. https://doi.org/10.1016/j.ijedro.2021.100038

Kulal, A., \& Nayak, A. (2020). A study on perception of teachers and students toward online classes in Dakshina Kannada and Udupi District. Asian Association of Open Universities Journal, 2414-6994.

Lestari, P. A., \& Gunawan, G. (2020). The Impact of COVID-19 pandemic on learning implementation of primary and secondary school levels. Indonesian Journal of Elementary and Childhood Education, 1(2), 58-63.

Lewis, S., Heath, N., Sornberger, M., \& Arbuthnott, A. (2012). Helpful or harmful? An examination of viewers' responses to nonsuicidal self-injury videos on YouTube. Journal of Adolescent Health, 51(4), 380-385. https://doi.org/10.1016/j.jadohealth.2012.01.013

Lincoln, Y., \& Guba, E. (1986). But is it rigorous? Trustworthiness and authenticity innaturalistic evaluation. New Directions for Program Evalluation, 73-84. https://doi.org/10.1002/ev.1427

MacIntyre, P. D., Gregersen, T., \& Mercer, S. (2020). Language teachers' coping strategies during the COVID-19 conversion to online teaching: Correlations with stress, wellbeing and negative emotions. System, 94, 102352. https:/ / doi.org/10.1016/j.system.2020.102352

Mishra, L., Gupta, T., \& Shree, A. (2020). Online teaching-learning in higher education during lockdown period of COVID-19 pandemic. International Journal of Educational Research Open, 1, 100012. https:// doi.org/10.1016/j.ijedro.2020.100012

Moser, K. M., Wei, T., \& Brenner, D. (2021). Remote teaching during COVID-19: Implications from a national survey of language educators. System, 102431. https://doi.org/10.1016/i.system.2020.102431

Murgatrotd, S. (2020). COVID-19 and Online learning. ResearchGate. https://doi.org/10.13140/RG.2.2.31132.85120

Murphy, M. P. (2020). COVID-19 and emergency e-learning: Consequences of the securitization of higher education for post-pandemic pedagogy. Contemporary Security Policy, 41(3), $492-$ 505. https:// doi.org/10.1080/13523260.2020.1761749

Nambiar, D. (2020). The impact of online learning during COVID-19: students' and teachers' perspectives. The International Journal of indian Psychology, 8(2), 783-793. https:// doi.org/10.25215/0802.094 
Nelz, J. (2020, August). Some teachers plan to retire due to hardships of distance learning. Phil News. $\quad$ https://philnews.ph/2020/08/20/some-teachers-plan-retire-hardships-distancelearning/

Niemi, H. M., \& Kousa, P. (2020). A case study of students' and teachers' perceptions in a finnish high school during the COVID pandemic. International Journal of Technology in Education and Science (IJTES), 4(4), 352-369. https:/ / doi.org/10.46328/ijtes.v4i4.167

Nnebedum, C., Obuegbe, A. S., \& Nwafor, H. E. (2021). Assessment of schools' reopening after COVID-19 closures. International Journal on Studies in Education (IJonSE), 3(2), 86-91. https:// doi.org/10.46328/ijonse.33

OECD. (2020, March 23). Education responses to COVID-19: Embracing digital learning and online collaboration. OECD. https://www.oecd.org/coronavirus/policyresponses/education-responses-to-covid-19-embracing-digital-learning-and-onlinecollaboration-d75eb0e8/

Olneck-Brown, B. (2021). Public education's response to the coronavirus (COVID-19) pandemic. National Conference of State Legislature. https://www.ncsl.org/research/education/publiceducation-response-to-coronavirus-covid-19.aspx

Parrocha, A. (2020). HEIs May hold limited face-to-face classes in MGCQ areas. Philippine News Agency. https://www.pna.gov.ph/articles/1105160

Patton, M. Q. (2002). Qualitative evaluation and research methods (3rd ed.). Sage Publications.

Paudel, P. (2021). Online education: Benefits, challenges and strategies during and after COVID19 in higher education. International Journal on Studies in Education (IJonSE), 3(2), 70-85. https://doi.org/10.46328/ijonse.32

Quezada, R. L., Talbot, C., \& Quezada-Parker, K. B. (2020). From bricks and mortar to remote teaching: A teacher education programme's response to COVID-19. Journal of Education for Teaching, 46(4), 472-483. https:// doi.org/10.1080/02607476.2020.1801330

Rapanta, C., Botturi, L., Goodyear, P., Guàrdia, L., \& Koole, M. (2020). Online university teaching during and after the COVID-19 crisis: Refocusing teacher presence and learning activity. Postdigital Science and Education, 2(3), 923-945. https://doi.org/10.1007/s42438020-00155-y

Rappler. (2020, October 8). A senior teacher struggles with online classes [Video]. YouTube. https://www.youtube.com/watch?app=desktop\&v=cz8_qMZ1jJQ

Rashid, S., \& Yadav, S. (2020). Impact of COVID-19 pandemic on higher education and research. Indian Journal of Human Development, 14(2), 340-343. https:// doi.org/10.1177/0973703020946700

Reinders, H., \& White, C. (2010). The theory and practice of technology in materials development and task design. In N. Harwood, Materials in ELT: Theory and practice (pp. 58-80). Cambridge University Press.

Ribeiro, V. V., da Silva, K., Guedes-Granzotti, R. B., César, C., Moreira, P. P., Santos, N., \& Dornelas, R. (2020). Stress and autonomic dysfunction symptoms related to voice in Brazilian university professors during the covid-19 pandemic. Logopedics Phoniatrics Vocology, 1-7. https:// doi.org/10.1080/14015439.2021.1939413

Roberts, M., Stewart, B., Tingley, D., \& Airoldi, E. (2013). The structural topic model and applied social science [PowerPoint slides]. https://mimno.infosci.cornell.edu/nips2013ws/ slides/stm.pdf

Samifanni, F. (2020). Japan's international education during COVID-19 pandemic: Show impact or face swift death. Asian Journal of Humanities and Social Studies, 8(4), 116-123. https:// doi.org/10.24203/ajhss.v8i4.6256

Schleicher, A. (2020). The impact of COVID-19 on education: Insights from education at a Glance 2020. OECD. https://www.oecd.org/education/the-impact-of-covid-19-oneducation-insights-education-at-a-glance-2020.pdf 
Simamora, R. M., Fretes, D. d., Purba, E. D., \& Pasaribu, D. (2020). Practices, challenges, and prospects of online learning during Covid-19 pandemic in higher education: Lecturer perspectives. Studies in Learning and Teaching, 1(3), 185-208. https:// doi.org/10.46627/ silet.v1i3.45

Slimi, Z. (2020). Online learning and teaching during COVID-19: A case study from Oman. International Journal of Information Technology and Language Studies, 4(2), 44-56.

Stachteas, P., \& Stachteas, C. (2020). The psychological impact of the COVID-19 pandemic on secondary school teachers. Psychiatriki, 31(4), 293-301.

Sun, A., \& Chen, X. (2016). Online education and its effective practice: A research review. JITE: Research, 15, 157-190.

Tariq, B., Dilawar, M., \& Muhammad, Y. (2019). Innovative teaching and technology integration: Exploring elderly teachers' attitudes. International Journal of Distance Education and E-Learning (IJDEEL), 5(1), 1-16. https:// doi.org/10.36261/ijdeel.v5i1.789

Tartavulea, C., Albu, C., Albu, N., Dieaconescu, R., \& Petre, S. (2020). Online teaching practices and the effectiveness of the educational process in the wake of the COVID-19 pandemic. Amfiteatru Economic, 22(55), 920-936. https:// doi.org/10.24818/ ea/2020/55/920

Tate, E. (2020, August 31). Survey: Nearly half of teachers have recently considered a job change as COVID-19 drags on. EdSurge. https://www.edsurge.com/news/2020-08-31-surveynearly-half-of-teachers-have-recently-considered-a-job-change-as-covid-19-drags-on

Todd, R. W. (2020). Teachers' perceptions of the shift from the classroom to online teaching. International Journal of TESOL Studies, 2(2), 4-16. https://doi.org/10.46451/ijts.2020.09.02

Toquero, C. M. (2020). Challenges and opportunities for higher education amid the COVID19 pandemic: The Philippine context. Pedagogical Research, 5(4), em0063. https:// doi.org/10.29333/pr/7947

UNESCO. (2020a, March). COVID-19 educational disruption and response. UNESCO. https://en.unesco.org/themes/education-emergencies/coronavirus-school-closures

UNESCO. (2020b). Global monitoring of school closures caused by COVID-19. UNESCO. https://en.unesco.org/covid19/educationresponse

UNESCO. (2020c). Closing schools has derailed the lives of kids all over the world. Here's how we can help them keep learning. UNESCO. https://en.unesco.org/news/closing-schoolshas-derailed-lives-kids-all-over-world-heres-how-we-can-help-them-keep-learning

Unger, S., \& Meiran, W. R. (2020). Student attitudes towards online education during the COVID-19 viral outbreak of 2020: Distance learning in a time of social distance. International Journal of Technology in Education and Science (IJTES), 4(4), 256-266. https:// doi.org/10.46328/ijtes.v4i4.107

UNICEF. (2020, July). UNICEF education COVID-19 case study: Malaysia - Empowering teachers to deliver blended learning after school reopening. Reliefweb https://reliefweb.int/report/malaysia/unicef-education-covid-19-case-study-malaysiaempowering-teachers-deliver-blended

USDLA. (2010). What is Distance Education. IGI Global. https://www.igiglobal.com/dictionary/distanceeducation/7981.

Watermeyer, R., Crick, T., Knight, C., \& Goodall, J. (2020). COVID-19 and digital disruption in UK universities: Afflictions and affordances of emergency online migration. Higher Education, 81, 623-641. https:// doi.org/10.1007/s10734-020-00561-y

Watson, J., Gemin, B., \& Ryan, J. (2008). Keeping pace with K-12 online learning: A review of state-level policy and practice. Evergreen Consulting Associates. https:// files.eric.ed.gov/fulltext/ED489514.pdf

Westgate, M., Barton, P., Pierson, J., \& Lindenmayer, D. (2015). Text analysis tools for identification of emerging topics and research gaps in conservation science. Conserv. Biol., 29(6), 1606-1614. https://doi.org/10.1111/cobi.12605 
Yang, X. (2020). Teachers' Perceptions of large-scale online teaching as an epidemic prevention and control strategy in China. ECNU Review of Education, 3(4), 739-744. https:// doi.org/10.1177/2096531120922244

Yang, Y., \& Cornelius, L. F. (2004). Students' perceptions towards the quality of online education: A qualitative approach. Association for Educational Communications and Technology, 27, 861-877.

Zhang, W., Wang, Y., Yang, L., \& Wang, H. C. (2020). Suspending classes without stopping learning: China's education emergency management policy in the COVID-19 outbreak. Journal of Risk and Financial Management, 13(58), 1-6. https://doi.org/10.3390/jrfm13030055 Zygomatic. (2003). Wordclouds. https://www.wordclouds.com/

\section{Author (s):}

* Faramarz Samifanni (Corresponding Author)

Fukuoka International University of Health and Welfare

137-1 Enokidu, Okawa City, Fukuoka 831-8501, Japan

Email: fredsami@takagigakuen.ac.jp

Rose Leslie R. Gumanit

Cebu Normal University

Cebu 6000, Philippines

Email: main.20000005@cnu.edu.ph 